\title{
Video games and Kahoot! as cognitive gamifiers in compulsory social isolation
}

\author{
Jhon Holguin-Alvarez ${ }^{1}$, Fernanda Taxa ${ }^{2}$, Evandro Tortora ${ }^{3}$, Joel Alanya-Beltran ${ }^{4}$, Jeidy \\ Panduro-Ramírez ${ }^{5}$, Cinthya Soto-Hidalgo ${ }^{6}$ \\ ${ }^{1}$ Universidad César Vallejo, Perú, jholguin@ucv.edu.pe, jhonholguinalvarez@gmail.com \\ ${ }^{2}$ Pontifica Universidade Catolica de Campinas, Brasil, fefataxa@ hotmail.com \\ ${ }^{3}$ Universidade do Estadual Paulista Júlio de Mesquita Filho, Brasil, evandro_tta@ hotmail.com \\ ${ }^{4}$ Universidad Tecnológica del Perú, Perú, joelalanya012@gmail.com \\ ${ }^{5}$ Universidad Tecnológica del Perú, Perú, jeidy5panduro@gmail.com \\ ${ }^{6}$ Universidad Nacional Mayor de San Marcos, Perú, csotoh@ unmsm.edu.pe
}

\begin{abstract}
Current educational gamifiers are based on the application of semi-formal and non-formal platforms to lead to more flexible learning in the current pandemic context. Given this, we propose the objective of investigating teaching and stimulating the learning of mathematical competencies in two Latin American contexts. We included in the first study 142 professors from the São Paulo Government of Brazil to study the use of the game through an evaluation by Kahoot! In another phase, we included 257 Basic Education teachers and 1,456 students from Peru to develop an experiment with non-serious video games. The conclusions allow us to argue that a large part of the teachers accept the Kahoot! Platform as an evaluating and gamifying means with equal effects to the use of traditional games in current education. Similarly, video games develop numerical thinking and mathematical reasoning in students who receive a virtual education in pandemic contexts. The contributions of the study also invite to introduce gamifiers as attitudinal increasing elements of complex learning in the classroom.
\end{abstract}

Key words: Educational Platforms, Gamification, Kahoot!, Mathematical Thinking, Social Isolation, Videogames, Virtual Learning.

\section{INTRODUCTION}

The educational processes of learning today, especially due to the appearance of $4 g$ and $5 g$ technologies, require the application of didactics that increase student interest and performance, even more so because they are immersed in digital communities practicing interactive habits that attract their Attention. Therefore, educational processes must allow the provocation of cognitive scaffolds in the student community through playful and meaningful pedagogical interactions. Part of the recreation and leisure industry is already found in university and school classrooms, especially due to the use of video games as means of informal learning in contexts with fluid and sustainable learning needs [1], [2]. Other investigations have proposed the inclusion of video games as pedagogical computers in the classroom [3], [4], [5], as well as the application of virtual games through mobile applications [6], [7]. In particular, the evidence so far reports that informal gamification through video games and learning platforms generate better learning in mathematical competencies [4], [8], in others the generation of reasoning is evidenced [5], [9], [10], which is why motivation and creativity are used as mediators, of the socio-emotional components and of the neuro-educational functions [11], [12], [13], [14].

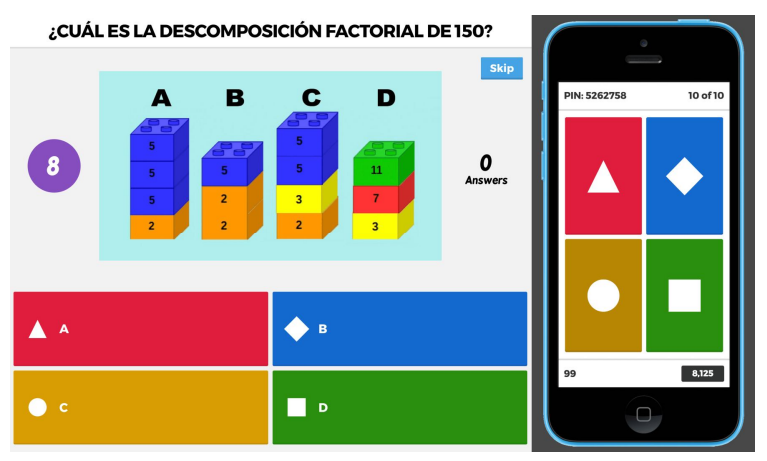

Figure 1: Kahoot! platform for the exercise of mathematics. Note: "What is the factorial decomposition of 150?" [Trad.].

Kahoot! (Figure 1), is a digital platform based on the methodology of participatory questionnaires. At the time of applying the questions, the teacher should project the questions on a screen to his students. They can answer questions, accessing the platform through the Internet browser (on a computer or mobile phone) and entering the game PIN (numeric code) followed by an alias. After the 
students access the site, they follow instructions, with which the teacher starts the contest process, obtaining medals for answers given by cognitive information about the course or subject. This attractive platform, both for its graphical interface and its modular practicality, was launched in 2013, with different presentations: (a) personal computer, (b) mobile, (c) tablets, among others. Research on the use of this platform reports that more than half of the subjects in school and university classrooms learn better using it compared to the use of pencil and paper [8], [15]. On the other hand, the use of Kahoot! In the classroom has caused students to take advantage of the constant verification of their learning with a greater intention of being evaluated, considering this activity as a reward for learning [15]. This evidence is also reflected in teachers who want to teach and learn to actively assess school or university cognition [16].

Regarding informal (non-serious) video games, these are considered as platforms without an oriented learning objective. Rather, they function as means of fun and leisure. From this perspective, gamification is considered as the recreational and motivational process of the teacher, whose purpose is to regulate the processes of: (a) learning, (b) metacognition, (c) evaluation, (d) feedback. It is a playful process that guides the development of rigid learning, which is dependent on complex higher processes such as problem solving, solving operations, reading and social skills.

Some results on gamification in learning have concluded that they allow the development of lower and higher cognitive processes [4], [17], [18], [19], [20]. Influential evidence has also been presented in the interaction processes through the immersion of mobile telephony in the learning of entrepreneurs from university contexts (García-Fernández et al., 2017), this form of gamification has been transfigured as a way of life of the school stage through transmedia education for active educational processes that use students' digital competences [21], [22]. In both cases, the inclusion of the video game favors self-esteem and motivation towards complex thinking [19], [23], [24], although the subjects who participate in video games are more competitive when learning at school or outside of it, achieving learning complexes [24], [25]. Although these are complex in the academic as well as attitudinal aspect, evidences that determine antisocial behaviors have also been reported [26].

In this last point, it is important to point out that two experiences have been experienced from vulnerable contexts that house individuals with economic deprivation, with social weaknesses in their immediate environment, who survive in the current pandemic state. Due to the states of pandemic in the world, and especially in Latin America, mandatory social isolation was established as a measure to prevent infections caused by SARS-CoVn2 (Covid-19). The first Supreme
Decree issued in March 2020 in Peru (D.S. $\mathrm{N}^{\circ}$ 046-2020-PCM), involved the development of virtual learning activities in universities and schools. Inasmuch as, the student communities were confined to the first stage of containing the virus, but at the same time, demanding that the general regulations be applied in all contexts (commercial, banking, economic, labor, among others). The research adopted two fundamental, coherent and necessary tools for the educational context in the face of the health situation that existed in the countries of Peru and Brazil. The first of our objectives was based on the usefulness of Kahoot!, to evaluate the implication of the game in teacher classes in Brazil. Another objective was to study the effects of the use that teachers make of video games in virtual classes (not face-to-face) for the learning of mathematical thinking in schoolchildren in Peru.

\section{METHODOLOGY}

The research was structured through two designs: (a) descriptive, (b) experimental. In the first, the use of traditional versus digital games is evaluated in the classes of 142 teachers of a training course carried out for teachers of the São Paulo Government of Brazil ( $M=45,6$ years of age; $S D=$ 2,6). In this part of the investigation we apply Kahoot! To evaluate the use of playful classes by teachers about their respective schools. In the second study, we conducted an experimental study with 257 Regular Basic Education teachers from Peru $(M=39,2$ years of age; $S D=3,1)$ y and 1456 third grade students $(M=8,9$ years of age; $S D=0,4)$ and fourth grade of primary school $(M=10,1$ years of age; $S D=$ $0,2)$, from public and private schools in Peru. All the participants joined the sample with the consent of the school directors and their parents. $56 \%$ of the total were integrated into the experimental group and $44 \%$ into the control group. In both contexts, compulsory social isolation was experienced as public measures of eventual governments.

\subsection{Instrument and procedure}

Regarding the instruments, for the first part of the study we used a questionnaire (CK) reflected in Kahoot!, distributed by WhatsApp messages in teacher training sessions in the city of Săo Paulo in Brazil. These were run by private and public universities. The instrument presented reliability $(\alpha=9,87)$ and validity $(v>98,5 \%)$ for its application in this context. For the second study, we applied an enactive, iconic and symbolic diagnostic evaluation (EIS), which evaluated higher numerical thinking through the dimensions: (a) numerical calculation ( $\alpha=9.82)$, (b) numbering $(\alpha=9.23)$. The test presented acceptable levels of reliability and validity. We also applied an adapted version of the Pre-Calculus Test $(P C)$ [27], in order to assess mathematical reasoning in children between 9 and 11 years of age. This test also presented 
acceptable reliability and validity indices $(\alpha=9.89 ; v>99 \%)$. The tests of the first study were applied during the teacher training period, complementing each other in a month. The tests of the experimental study were applied before and after the Acción Ludos program. Figure 2 describes information related to video games in the program called Acción Ludos, as well as the use by some of the students. Through this program we apply 25 additional class minutes to the hours executed in virtual classes in six months of virtual learning.
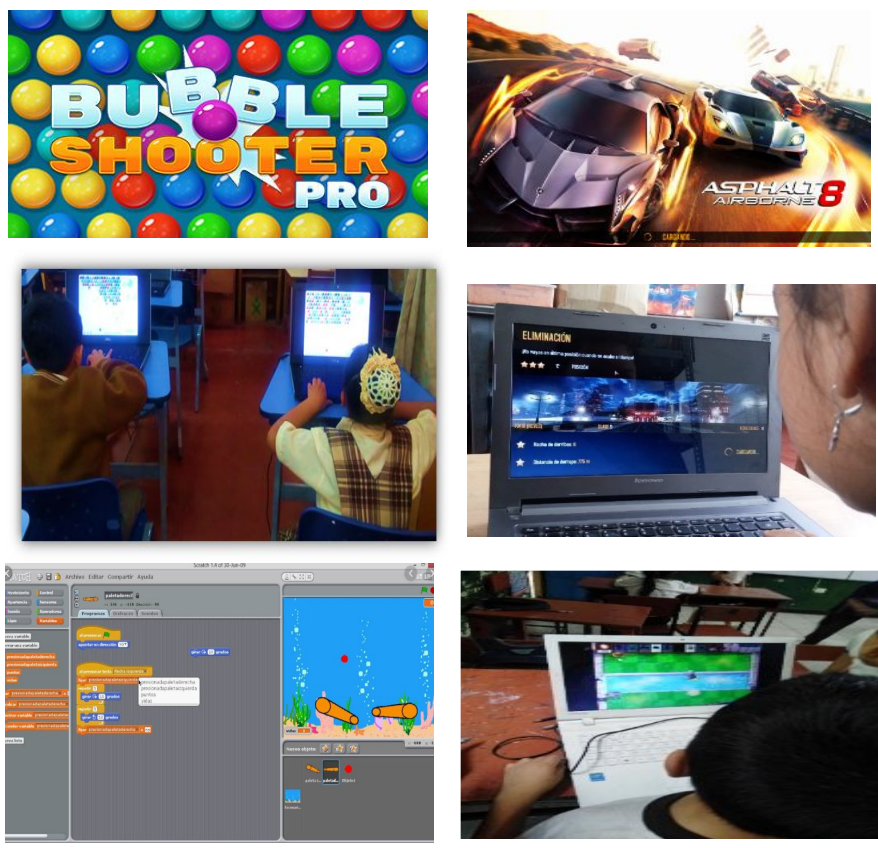

Figure 2: Video game exemplification of the Acción Ludos program and some isolated activities.

We structured the program with 150 class sessions gamified by eight informal video games: (a) Bubble Shooter Pro, (b) Asphalt 8 Airbone, (c) Scratch, (d) Bubble Shooter 3D; (e) Asphalt 8 Airbone; (f) Plants \& Zombies, (g) Minecraft, (h) Roblox. We use tablets, personal computers and cell phones for the installation of video games and the execution of the learning sessions. It is important to note that, due to pandemic contexts, students take two to three synchronous hours of teaching daily, and two asynchronous hours of individual and collective learning according to their own educational institutions.

\section{RESULTS}

\section{Games in Cognition: Evaluation in Kahoot!}

The first part of the study presented interesting results regarding the usefulness that Brazilian teachers gave to traditional games, including board, personal and virtual games. Therefore, their belief, disposition and evaluation in the implication of these in their learning sessions and in the general interaction that they generate in their educational centers was examined and compared.
Table 1: Percentage of utility of the games using Kahoot!*

\begin{tabular}{|c|c|c|}
\hline Ítems & Tradicional & Virtual \\
\hline Constant application & 36 & 64 \\
\hline Motivation of the game & 84 & 16 \\
\hline Provoker of challenges & 75 & 25 \\
\hline Best gamifier & 79 & 21 \\
\hline Positive feelings & 71 & 29 \\
\hline
\end{tabular}

Source: Research database.

Note: *Analysis based on the best alternative (5 pts.) ** Only questions with greater interest were introduced.

Due to the first objective, the evaluation through Kahoot!, allowed to distribute the CK questionnaire to the amount of sample available in the study. The results issued in table 1 reflect the interest of teachers in applying virtual strategies by applying video games or interactive teaching platforms, with more than $50 \%$ of the total constantly seeking to apply them in their learning sessions, although there is a significant percentage who do not stop demanding the development of traditional activities in students. On the other hand, there is a great predilection for applying traditional games as a resource that awakens interest in students to study. Although more than $20 \%$ and $28 \%$ reflect digital gamification as a pure learning experience, which is consistent with other studies that have found that teachers tend to change their strategies adopting technological ones to generate systematic learning on platforms that provoke cooperative and personalized learning [8], [15], this has been crucial due to the academic and non-academic awards that this type of class work includes [15], [16].

On the other hand, it is important to note that more than $20 \%$ of the sample from Brazil has indicated that virtual games are better gamifiers. This is something positive, since in traditional education there is a certain nullity in pedagogical thinking that implies the use of video games, platforms, devices and digital tools in face-to-face classrooms, when evidence reveals that higher learning skills are stimulated in virtual learning [4], [17], [18], as well as the development of attitudes towards the game. That is, young people and children learn cognitively adapting, and involve the development of their own attitudes [19], [21], [22], [24]. In the same way, we can accept that although gamification styles were not studied, teachers can adapt to methods that can generate better learning rates, more fluid reactions to conceive data in the shortest possible time, and even to modify the numerical conceptual thinking [2], [17], [20], [18]. Finally, in the context of Brazil, the situation of isolation has become imposing, since face-to-face teaching has had to turn its perspective in a short time. The value of gamification allows schools to progress in the shortest time possible, especially in this age in which we find ourselves. 


\section{Informal Video Games: Gamifying Experiment}

Regarding the second part of the study, it is described in Figure 3 that there were equitable measures in the percentages of both participating groups in the pretest measurement, although with minimal differences between the initiation level between the experimental and control groups $(6 \%)$ and at the level of achievement $(5 \%)$, these were not significant in the subsequent statistical analysis $\left(t_{(1450)}=-3,201 ; p>.001\right)$. On the other hand, we observed that in the post-test measurement of both groups there were differences at the descriptive level, since the percentage of subjects who performed at a low level (initiation) decreased in the experimental group of more than $50 \%$ of participants. It is also observed that in the level of achievement the increase of more than $30 \%$ of the total of this group prevailed. We found significant differences in the comparison of group scores in the posttest measurement $\left(t_{(1451)}=-5,677 ; p<.001\right)$, which was favorable to the experimental group $(M=157,25 ; S D=$ $1,78)$.

\section{(a)}

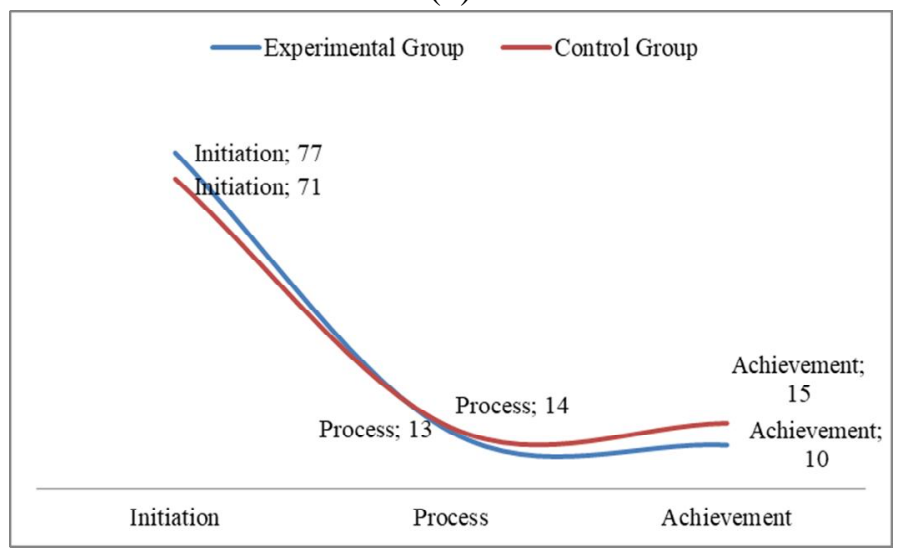

(b)

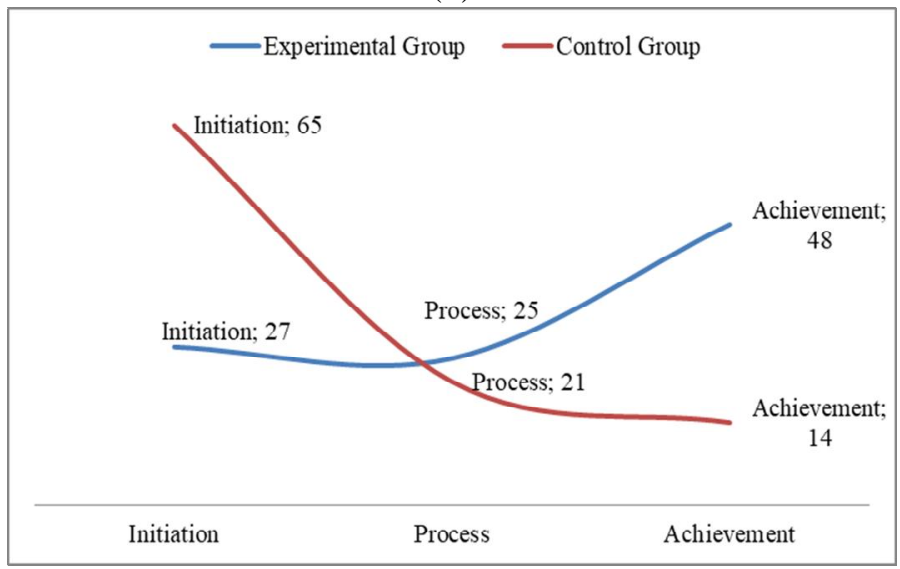

Figure 3: Description of percentages in pretest $(a)$ and posttest $(b)$ measurements in higher numerical thinking.

Note: Research database.
This change was able to determine the effects of the Acción Ludos program, from the inclusion of video games. Here we can reflect that the effects of these games aroused motivation and interest in the participants in the experimental group, which was a major indicator to accept that mathematical ability was also developed in the numerical aspect. Although the differences exemplify that videogames caused sustained fluidity in the search for solutions, and in the shortest possible time. These evidences are similar to others that found benefits in the use of accompanying or integrated gamifiers to classroom learning, developing speed, concentration and response automation [4], [20]. On the other hand, here it has also been crucial the implication in the development of new predispositions towards the game in students who only thought about learning vertically, as has happened in other investigations [4], [18], [19]. This rigid learning figure appears in most Latin American schools that follow schematic teaching patterns.

\section{(a)}

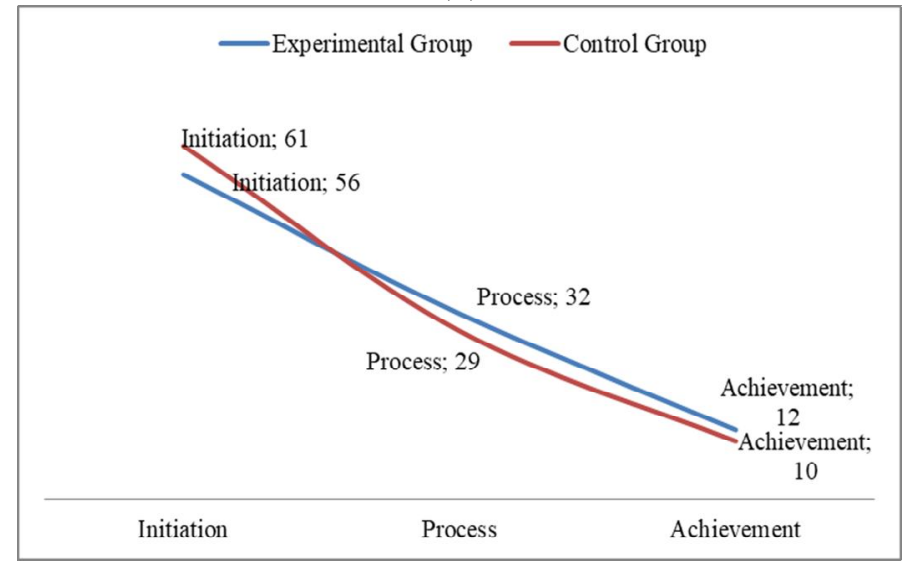

(b)

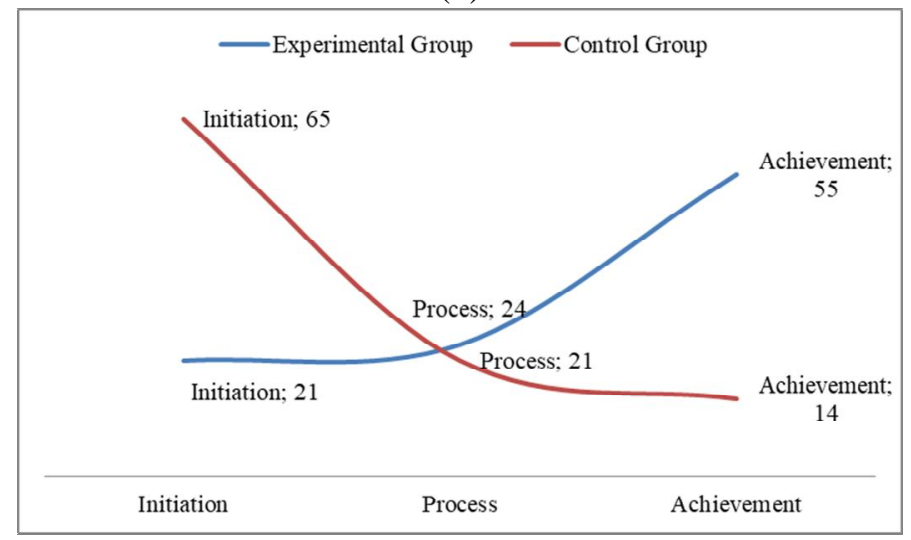

Figure 4: Description of percentages in pre-test $(a)$ and post-test $(b)$ measures of mathematical reasoning. Nota: Research database.

The analysis of the effects on mathematical reasoning is described in figure 4 , showing equitable percentages in the pretest measurement, presenting differences of $4 \%, 3 \%$ y 2 $\%$ in the comparison of grouping of individuals who reached, 
respectively, the initiation levels, process and achievement. These differences did not present statistical significance at the beginning of the process (pre-test) $\left(t_{(1321)}=-2,181 ; p>.001\right)$, so we can argue that the scores between both groups of subjects were similar, their abilities related to reasoning were found stable before starting the program. However, a lower percentage of subjects who performed at the baseline level can also be observed between both groups in the post-test measurement, being lower in the experimental $(n>40 \%)$. On the other hand, there were notable differences in the category achieved (41\%) between both groups. These final differences were corroborated by statistical analysis, being significant in non-parametric tests $(M d n=38,76 ; S D=0,69)$ as well as in parametric tests $\left(t_{(1450)}=-4,355 ; p<.001\right)$.

These evidences reveal that there are very flexible pedagogical processes that allow the acquisition of information much faster and more exact in exercises that are accompanied by stress relievers that can be generated in routine activities [3], [5], [8]. Therefore, the applied gamifiers (video games) encouraged in two ways: (a) cognitive companions, (b) attitudinal dissipators. In this sense, there would be new evidence to report as a contribution of the study, regarding the surprise or motivational factor that they generate in rigid or vertical tasks. We have found that students learn faster with gamifiers, but they also acquire new attitudes over time, if these accompany cognitive processing in the classroom.

\section{CONCLUSIONS}

Regarding the Kahoot! tool, this has become the means of cognitive evaluation, as well as a processor of feedback from teachers, who seek in their strategies to generate new learning through games, but use this program as beneficiaries of learning, and of your own checking. We conclude that this gamification strategy can be reflective for teachers as well as for students, the traditional game can be equated to a large extent by teachers, who are adopting new expectations in the face of this resource, using it as an instrument of playful mediation.

In terms of video games, they have served as mental stimulators, strengtheners of cognitive fluency. In turn, as beneficiaries of attitudes to learn in the current pandemic context. In the countries of Brazil and Peru, the subjects learned to develop their reasoning and numerical thinking as the first evidence that virtual education can generate processes of cognitive satisfaction in the contexts of compulsory social isolation addressed.

\section{REFERENCES}

1. Scolari, C.A. Informal learning strategies, in Adolescents, the media and collaborative cultures.
Taking advantage of the transmedia skills of young people in the classroom, Carlos A. Solari (Ed.), Barcelona: Universitat Pompeu Fabra, 2018. pp. 83-93.

2. Holguin-Alvarez, J.; Montañez-Huancaya, A.; Ledesma-Pérez, F.; Cruz-Montero, J. \& Figueroa-Hurtado, F. Modification of Logical Reasoning through an Informal Gamification Platform. International Journal of Advanced Trends in Computer Science and Engineering, Vol. 9, no 4, pp. 6496-6500, 2020.

https://doi.org/10.30534/ijatcse/2020/336942020

3. Li, Z.Z., Cheng, Y.B. \& Liu, C.C. A constructionism framework for designing game-like learning systems: Its effect on different learners. British Journal of Educational Technology, Vol. 44, no 2, pp. 208-224. 2013.

https://doi.org/10.1111/j.1467-8535.2012.01305.x

4. Glaser-Opitz, H. \& Budajová, K. THE MATH - open source application for easier, Acta didactica Napocensia, Vol. 9, no 1, pp. 45 - 50. 2016. https://eric.ed.gov/?id=EJ1103424

5. Dos Santos, G. \& Gomes, C. As contribuições do jogo rouba monte no desenvolvimento de estratégias de contagem por crianças do terceiroano do ciclo de alfabetização, Revista de Educação, Ciências e Matemática, Vol. 6, no 2, pp. 42 - 60. 2016.

http://publicacoes.unigranrio.edu.br/index.php/recm/art icle/view/4029

6. Martín, M., Gómez, V. B. \& García, A. A quantitative approach to pre-service primary school teachers' attitudes towards collaborative learning with video games: previous experience with video games can make the difference. International Journal of Educational Technology in Higher Education, 14, 1-18. 2017.

https://doi.org/10.1186/s41239-017-0050-5

7. Martins, C. \& Giraffa, L.M.M. Gamificação nas práticas pedagógicas: teorias, modelo e vivências. Nuevas ideas en informática educativa - TISE. 2016. http://www.tise.cl/volumen11/TISE2015/42-53.pdf

8. Wang, A. I., \& Tahir, R. The effect of using Kahoot! For learning - A literature review. Computers and Education, Vol. 149, pp. 103818, 2020. https://doi.org/10.1016/j.compedu.2020.103818

9. Fuentes, V.P. \& Quilcate, L.I. Reading comprehension and choice of operation for solving arithmetic problems according to gender in schoolchildren who attend the 4th grade of primary school in a public school in Huaraz (Master's Thesis), Pontificia Universidad Católica del Perú, Lima, Perú, 2015.

10. León, V. Lucano, V. \& Oliva, J. Development and application of a program to stimulate mathematical competence for first grade children of a national school (Master's Thesis), Pontificia Universidad Católica del Perú, Lima, Perú, 2014.

11. Hervás, C.; Ballesteros, C. \& Corujo, M. Robotics and curriculum: experimenting with new methodological 
and didactic strategies for their curricular integration, In Hispano-Ecuadorian investigative and innovative experiences. María Compte; Eloy López; María Morales y Antonio Martín, Sevilla, España: AFOE., pp. 77-93, 2018.

12. Teixes, F. Gamification: fundamentals and applications. Catalunya: editorial UOC, 2014.

13. Revuelta, F.I. \& Pedrera, M.I. Neuro-educational and socio-emotional bases for working with video games in learning contexts. Edmetic, Journal of Media Education and ICT, Vol. 7, no 2, pp. 5-9, 2018. https://doi.org/10.21071/edmetic.v7i2.11147

14. Sudarmilah, E.; Ayub, I.H.; Puspa, D.A.; Dinar, W.; \& Yuliana, I. Game Education of Disaster Mitigation: A Systematic Literature Review. International Journal of Advanced Trends in Computer Science and Engineering, Vol. 8, no 6, pp. 2940-2943, 2019. https://doi.org/10.30534/ijatcse/2019/42862019

15. Monteiro, J. C. S., Rodrigues, S. F. N., \& Pinheiro, S. C. B. App-learning: contribuições do Kahoot no Ensino de Jornalismo. Revista Observatório, Vol. 5, no 6, pp. 1-24, 2019. https://doi.org/10.20873/uft.2447-4266.2019v5n6p305

16. Correia, M., Santos, R. A. Aprendizagem baseada em jogos online: uma experiência de uso do Kahoot na formação de professores in Atas do XIX Simpósio Internacional de Informática Educativa e VIII Encontro do CIED - III Encontro Internacional, 2017, pp. 252-257, Ponte, C., Dodero, J. M., Silva, M. J., Lisboa: CIED - Centro Interdisciplinar de Estudos Educacionais.

17. Armier, D. D., Jr.; Shepherd, C. E.\& Skrabut, St. Using Game Elements to Increase Student Engagement in Course Assignments, College Teaching, Vol. 64 no 2, pp. 64-72, 2016.

http://dx.doi.org/10.1080/87567555.2015.1094439

18. Martyniuk, S. V. Game On!--Teaching Video Game Studies in the Arts Classroom. Art Education, Vol. 71, no 3, pp. 14-19, 2018. http://dx.doi.org/10.1080/00043125.2018.1436325

19. Squire, K. \& Jenkins, H. (2003). Harnessing the power of games in Education. Insight Vol. 3, pp. 7-33, 2003. https://www.academia.edu/1317074/Harnessing_the_po wer_of_games_in_education

20. Huiza, F. \& Holguin, J. Gamification based on a video game that allows the development of tasks with high cognitive demand. Eduser, Vol. 6, no 1, 63-77, 2019. https://doi.org/10.18050/eduser.v6i1.2179

21. Sergeeva, M.G.; Ogurechnikova, N.L.; Zarembo, G.V.; Nikashina, N.V.; Nagornova, E.V.; Vasilenko, S.A.; \& Baranova, E.A. Methodology Development of the University Teacher's Creative Abilities with the Help of Information Technologies. International Journal of Advanced Trends in Computer Science and Engineering, Vol. 8, no 6, pp. 2800-2805, 2019. https://doi.org/10.30534/ijatcse/2019/19862019

22. Al Irsyadi, F.Y.; Supriyadi, Kurniawan, Y.I. Interactive Educational Animal Identification Game for Primary
Schoolchildren with Intellectual Disability. International Journal of Advanced Trends in Computer Science and Engineering, Vol. 8, no 6, pp. 3058-3064, 2019. https://doi.org/10.30534/ijatcse/2019/64862019

23. Aznar-Díaz, I., Raso-Sánchez, F., Hinojo-Lucena, M. A. y Romero-Díaz, J. J. Perceptions of future teachers regarding the potential of gamification and the inclusion of video games in the teaching-learning processes. Educar, Vol. 53, no 1, pp. 11-28, 2017. http://dx.doi.org/10.5565/rev/educar.840

24. Salas, R.A. Students' perspectives on the inclusion of video games in learning. IJERI, International Journal of Educational Research and Innovation, Vol. 10, pp. 163-178, 2017.

https://www.upo.es/revistas/index.php/IJERI/article/vie w/2613

25. Tatli, Z. Traditional and Digital Game Preferences of Children: A CHAID Analysis on Middle School Students. Contemporary Educational Technology, Vol. 9, no 1, pp. 90-110, 2018. http://www.cedtech.net/past2.asp?numara=91

26. Sola, J.M.; García, M. \& Ortega, M. The implications of the use of mobile devices in the teaching-learning process in 5th and 6th grade students. PIXEL BIT, Revista de Medios y Comunicación, Vol. 55, 2019. https://doi.org/10.12795/pixelbit.2019.i55.04

27. Milicic, N. y Schmidt, S. Precalculus Test. Santiago de Chile: Universitaria S.A., 2002. 